\title{
Hobbes às avessas: 0 direito natural e a crise da democracia liberal
}

\author{
Bruno Simões \\ Universidade de São Paulo \\ brunosim@usp.br
}

resumo Nas décadas de 1920 e 1930, Carl Schmitt e Leo Strauss estabeleceram leituras distintas, e em parte complementares, do legado filosófico-político de Thomas Hobbes, especialmente da fundação moderna do direito natural e da conseqüente decadência do Estado em virtude dos fenômenos da neutralização e despolitização. Nosso objetivo, na retomada de suas críticas ao liberalismo, é delimitar uma possível gênese do pensamento conservador a partir do legado intelectual desses autores.

palavras-chave Hobbes; Leo Strauss; Carl Schmitt; direito natural; democracia liberal

Em 1932, na conclusão de seu artigo Notas sobre o Conceito do Político de Carl Schmitt, Leo Strauss anuncia: "Uma crítica radical do liberalismo só pode ser levada a cabo com base num entendimento adequado de Hobbes" (STRAUSS, 1995, p. 119). E em 1927 Carl Schmitt posiciona, em sua obra $O$ Conceito do Político, a "eterna conexão entre proteção e obediência", referindo-se à verdade política vivida por Hobbes em tempos de guerra civil. Ora, a sentença seguinte de Schmitt - "o protego ergo obligo é o cogito ergo sum do Estado" -, embora possa ser considerada peremptória naquilo que apreende da filosofia política de Hobbes, não é o bastante do ponto de vista da análise do político com vistas à crítica da democracia liberal. $\mathrm{Na}$ tarefa de protetorado assumida pelo Estado, encontra-se, de modo latente, "a essência de sua existência política”, qual seja, "determinar por si mesmo a diferenciação do amigo e do inimigo" (SCHMITT, 1992, p. 76-78). 
Para além do dever de obediência dos membros de uma nação - ato e pensamento que respondem pela preservação de suas vidas e pela ordem civil - resta a relação interestatal que, para Schmitt, se dá sob a forma da dominação; relação também considerada pelo próprio Hobbes como uma espécie de reposição do estado de natureza, ou do status belli, projetada num quadro de nações individualizadas.

O que se questiona, no âmbito da preocupação com o bem-estar social, é que, se a ordem interna do Estado estivesse assegurada por força da determinação da soberania, a "vida política" correria o risco de deixar de existir na ausência da diferenciação entre amigo e inimigo. Sob pena de o Estado aniquilar-se, a paz (fim último da unidade soberana em Hobbes) não pode ser encerrada ou resolvida internamente, e revive, contrariamente a intenções modernizantes, a própria realidade do conflito. Em última análise, o almejo pacifista, como projeto acabado do político, além de representar o seu próprio fim - pois o político se expressa por meio da decisão beligerante -, não passa de um logro ou de uma falta de entendimento que, segundo Schmitt, "turva" o conhecimento dessa realidade fundamental, impedindo a constatação da "periculosidade" permanente, para a qual Hobbes já teria apontado. É, portanto, num período de mudanças profundas no cenário político alemão que entram em cena Carl Schmitt, Leo Strauss e o autor tratado por ambos, Thomas Hobbes, para o debate da questão a mais premente possível: a posição do político.

Schmitt refaz o percurso da soberania hobbesiana - o que não deixa de ter um efeito anacrônico que enseja, ao mesmo tempo, a busca do permanente - e empreende a edificação do "conceito do político" como resposta combativa aos fenômenos da "neutralização e despolitização" (Neutralisierungen und Entpolitisierungen), que assolam o panorama das democracias liberais na Europa. Já Strauss, dando parcialmente créditos ao "ponto de partida" crítico traçado por Schmitt - e talvez apenas na condição de ponto de partida - imiscui-se, por assim dizer, na própria sintaxe schmittiana, para revelar os motivos ocultos que perpassam essa crítica de Schmitt. Ao mesmo tempo, Strauss avalia as deficiências político-institucionais de então, que, em vez de serem apenas reflexos da negligência com que o liberalismo tratou o domínio do político, são frutos da própria semente liberal lançada por Hobbes no início da modernidade, remetendo todo esse debate para o fundo moral da questão. 
É nítida a colaboração entre os dois intérpretes da obra de Thomas Hobbes se faz presente.Vela-se, porém, os propósitos que ambos têm com suas críticas.

De modo preciso, o quadro histórico proposto por Strauss é bastante elucidativo: na Europa seiscentista, ainda não liberal, Hobbes funda o liberalismo, graças principalmente à sua defesa da inalienabilidade do "direito natural", tributada a indivíduos que compõem e, desse modo, determinam os limites do Estado moderno (STRAUSS, 1995, p. 102). Por outro lado, pondera Strauss, na "sistemática surpreendentemente coerente do liberalismo", Schmitt elabora uma crítica que, como etapa inicial, dissipa o horizonte liberal de caráter neutro, relativista e, sobretudo, débil ou apalermado, alavancando uma nova égide (contrária aos rumos progressistas da história da modernidade) gestada em retrospecto ao que lhe parece ser o grande achado de Hobbes, que teria afirmado a necessidade da soberania na unidade política. Nessa mesma interpretação schmittiana de Hobbes que, vale dizer, é a leitura desvendada por Strauss - o vínculo entre proteção e obediência teria outrora preservado a "ordem das coisas humanas", num sentido que para Strauss é o mais profundo possível: Schmitt afirma o "Estado total", em que os membros da unidade estariam dispostos de fato (e não apenas sob os ditames de enunciados teóricos) ao sacrificio de suas vidas em nome da totalidade política.

Mas, como tendência predominante, o que se evidencia, à época dos dois intelectuais alemães, difere bastante dessa disposição ao sacrificio. $O$ Estado, mesmo salvaguardado na sua unidade política, situa-se como que "subalterno" da sociedade, a qual, por sua vez, passa a "ter sua ordem em si mesma":

"as negações do Estado e do político, [propiciadas pelo liberalismo burguês] suas neutralizações, despolitizações e declarações de liberdade possuem igualmente um determinado sentido político [desprovidas contudo de qualquer radicalidade política] e se dirigem polemicamente, numa determinada situação, contra um determinado Estado e seu poder político. Só que estas não são propriamente uma 
teoria do Estado ou uma idéia política. O liberalismo decerto não negou radicalmente o Estado, mas, por outro lado, também não encontrou nenhuma teoria positiva do Estado e nenhuma reforma própria ao Estado, mas procurou, isto sim, prender o político ao ético e subordiná-lo ao econômico; ele criou uma doutrina da divisão e do equilíbrio dos 'poderes', isto é, um sistema de obstáculos e controles do Estado que não se pode designar como teoria do Estado ou princípio de construção político" (SCHMITT, 1992, p. 87).

O sentido "polêmico" do político se vê ameaçado por um amplo processo "pacificador", repleto de contradições institucionais, a exemplo da Liga das Nações ou do Pacto de Kellogg (Cf. SCHMITT, 1992, p. 134-135), que expressariam um desejo de segurança do status quo, a ser alcançado no "Estado Universal". Contudo, a belicosidade do estado de natureza, que Hobbes determina na ausência das balizas políticas do Estado civil, permite a Schmitt afirmar a posição do político, ou seja, do conflito, haja vista o espectro internacional, que não é de um universo, mas de um "pluriverso" de nações.

O panorama europeu que deslancha essa breve parceria ${ }^{1}$ entre Strauss e Schmitt reflete um profundo desengano em relação ao que se convencionou chamar de projeto moderno. O malogro da República de Weimar, em cujo colapso já se constatava a olhos vistos a organização de grupos políticos que punham em jogo a ordem estatal (a exemplo do nacional socialismo, do comunismo, do anarquismo e do socialismo democrático) atesta, para Schmitt, o preâmbulo do esfacelamento político. Assim, o enfraquecimento institucional do Estado prussiano (a sua derrota na $1^{\text {a }}$ Guerra Mundial e o humilhante armistício a que se submete, em seguida, por força do Tratado de Versalhes) evidencia, de maneira radical, uma ordem política esmaecida e relativizada, em que cada um desses grupos busca a sua hegemonia. E, sobre este ponto, embora Schmitt trate especificamente da guerra civil inglesa no século dezessete, não há dúvidas de que alude ao seu próprio tempo: “Quando, no interior de um Estado, partidos organizados estão em condições de garantir aos seus afiliados mais proteção do que o Estado, então o Estado se torna, na melhor das hipóteses, um anexo destes partidos, e o cidadão individual saberá a quem deve obedecer" (SCHMITT, 1992, p. 79). 
Diluindo-se num conjunto de medidas ineficazes - um Parlamento transformado em palco de um "sistema pluralista", que mais enfraquecia o Estado do que assegurava a sua soberania - era como se os ares de uma guerra civil ou, em termos conservadores, de um caos social, sinalizasse a perda irreparável de uma realidade que presidia fundamentalmente o "estatuto do político" - que para Schmitt se mostra na própria maneira apaziguada pela qual o pensamento liberal passou a tratar as situações de conflito: "O liberalismo procurou, a partir de seu típico dilema entre espírito e economia [...] reduzir o inimigo a um concorrente, na perspectiva da economia, e a um oponente de discussões, na perspectiva do espírito" (SCHMITT, 1992, p. 54). O que se tem, como dissemos, é um significado turvado do político, desprovido, pois, de seu caráter polêmico, que passa, num esquecimento progressivo, a ser tratado como uma “abstração vazia”.

Desse modo, a fragilidade da jovem democracia liberal na República de Weimar municia Schmitt, que considera tal momento político como o fim de uma era, permitindo a Strauss a elaboração de uma crítica da filosofia da cultura (Kulturphilosophie), como objetivo teórico a se desdobrar durante toda a sua trajetória intelectual. Num contexto mais profundo, o progresso científico e o primado da técnica, como meios emergentes e prevalecentes de dominação da natureza, culminam na afirmação de uma política lapidada pela idéia de que a riqueza e a abundância produtiva contornariam, de uma vez por todas, os perigos que ameaçam a vida humana. Ao pagar-se o preço da segurança, em prol da preservação de cada indivíduo, a transição para o liberalismo "negou" o político em nome da paz social e expressou seu ideal civilizador na institucionalização racional da convivência humana, transformando-se, nas palavras de Schmitt, numa "comunidade de consumo e produção" (Konsumun und Produktivgenossenschaft). Os setores da cultura, da religião, da educação, da economia, dentre outros, passam a se mostrar simplesmente desvinculados de um Estado que, na verdade, existe para preserválos em sua autonomia. O "pensar e o agir humanos" - regrados outrora pelo pressuposto de uma "eventualidade do conflito", dada a "possibilidade de extinção" que incidia diretamente sobre o modo de vida dos agrupamentos sociais - orientam-se, no mundo liberal, sem a preocupação básica, e cada um dos setores da sociedade elencados por Schmitt 
comporta-se como se o político não fizesse mais parte de suas ocupações específicas. O que, conforme trataremos, não passa de uma ilusão para ambos os críticos.

Estamos às voltas com um sinistro resgate, em pleno século vinte, da consagrada "condição natural da humanidade", em que, conforme Hobbes caracteriza no capítulo quinze do Leviatã,"cada homem é inimigo de cada homem por falta de um poder comum que os mantenha a todos aterrados" (HOBBES, 2003, p. 126). E o que parece mais marcante nessa retomada é que, se o intento de Hobbes, com a caracterização da beligerância no estado de natureza, objetiva o estabelecimento da paz, e se em função disso a soberania do Estado é firmada na sua base racional, que tem primordialmente em conta a segurança de cada membro da sociedade, para Schmitt e Strauss, entretanto, o propósito de suas análises está na própria ênfase da eminência do conflito, conferindo ao medo terrificante da morte violenta um elemento natural substancioso frente à vida social tecnicizada.

Se, com O Conceito do Político, Schmitt caracteriza o liberalismo como "resultado" da modernidade em vias pacificadoras e prognostica, a contrapelo dessa realização, a manutenção urgente de uma realidade baseada no "enfrentamento e combate do inimigo", sob pena de perderse por definitivo o caráter político da vida humana, Strauss, por sua vez, passa a ver mais do que isso. Para este último - que tem em conta o fato já apontado por Schmitt de que um processo de trezentos anos atinge o seu fim (Ziel) - o fenômeno da despolitização é o "objetivo autêntico e original" do mundo moderno. Todavia, frente ao fracasso que Schmitt e Strauss procuram (ou querem) entrever na organização política do liberalismo, é possível ainda resgatar a "posição do político".

Um dos principais pontos dessa interlocução diz respeito ao gênero (genus) que responde pela especificidade do político na sua "determinação conceitual". No mundo liberal, em que a organização (Ordnung) do saber mostra-se problematicamente segmentada, o gênero a que o político passa a pertencer é o da "cultura"; esta última entendida por Strauss como 
a "totalidade do pensamento e ação humanos, dividida em vários domínios relativamente independentes" - ao assim se expressar, Strauss já traça os vínculos originais que o projeto moderno tece com o status civilis hobbesiano, que vem a se tornar o pressuposto de toda cultura (no sentido das artes e ciências) e o elemento que aparta o homem da natureza, à medida que a política passa a ser entendida como "disciplina da vontade humana" (STRAUSS, 1995, pp. 94-98).

Num sentido primevo e forçosamente indelével, Schmitt já havia estabelecido de modo lapidar: “A específica distinção política, à qual as ações e motivos políticos podem ser reconduzidos, é a distinção entre amigo (Freund) e inimigo (Feind)" (SCHMITT, 1992, p. 51). Há, portanto, um critério central que subsiste por si mesmo e que, no apelo à sua concretude, se lança, enquanto gênero, acima das distinções características da autonomia de outros âmbitos (Sachgebiete): na economia (o útil e o danoso, ou o rentável e o não rentável), na moral (o bem e o mal) e na estética (o belo e o feio).

Não se trata, porém, de um “âmbito próprio" como os outros, nem de uma "definição exaustiva ou especificação de conteúdos", mas sim de um "critério" extraído da sua concretude existencial. Como pressuposto, a antítese determinante do conceito do político "designa", de maneira fundamental, "o grau de intensidade extrema de uma união ou separação" (SCHMITT, 1992, pp. 108-109). Segundo Schmitt, que o inimigo seja "existencialmente algo outro" e que isso possa ser tomado como possibilidade de ameaça, eis as condições que atestam a permanência do conflito. Garante-se, assim, um pensar e um agir únicos, voltados necessariamente para a eventualidade e a finalidade do combate - seu intento, com tal diferenciação, confere uma realidade existencial ao fenômeno do político, passando ao largo de reduções conceituais e de normatizações "previamente estipuladas". Na determinação do elemento alheio, decidida à luz do critério amigo ou inimigo e, portanto, considerada no sentido da tomada de posição frente a uma possível ameaça, Schmitt depreende uma instância concreta que, incidindo sobre o modo de vida, só pode ser enfrentada por meio do embate, em que cada um dos envolvidos "tem de decidir por si mesmo se a alteridade do estrangeiro [...] representa a negação da sua própria forma de existência, devendo portanto ser repelido e combatido, para a preservação da sua própria forma de vida”. 
Com efeito, o político atesta sua presença nos mais diversos setores da vida humana, em que se pode constatar esse "grau de intensidade de associação ou de dissociação". Por esse critério, tudo passa em última análise a ter um caráter potencialmente político, ou pelo menos a ser afetado pela decisão política, embora, "no sentido da palavra, o político" não se reduza e até mesmo prescinda, "teórica e praticamente", de tais âmbitos: "o inimigo político não precisa ser moralmente mau, não precisa ser esteticamente feio; não tem que surgir como concorrente econômico, podendo talvez até mostrar-se proveitoso fazer negócio com ele" (SCHMITT, 1992, p. 52).

Com isso, o enaltecido domínio da cultura perde a relevância que o liberalismo lhe conferira. E o argumento traçado por Schmitt é crucial: por mais que reivindique a autonomia interna de seus âmbitos, a cultura não é suficiente para lidar com a "possibilidade real da morte" numa situação extrema. ${ }^{2}$ A “originalidade ontológica” da luta contra o inimigo, para a qual aponta Schmitt, comporta uma dimensão muito mais abrangente do que a organização da sociedade orientada pela cultura, haja vista a "possibilidade real de aniquilamento", e, em relação à qual, nenhum dos diversos ramos pode responder satisfatoriamente.

Nessa espécie de fenomenologia existencial do político, Schmitt quer garantir a concretude e a inescapabilidade de uma tensão que se dá a conhecer pela ameaça emergente ao modo de vida de um "agrupamento humano" - ou "unidade política" conforme enuncia; a respeito da qual, Schmitt é categórico: "ela existe ou não existe" - neste último caso, ela obviamente não mais existe por ter sido eliminada ou, no mínimo, enfraquecida graças à decisão de combate tomada por outro agrupamento, que contou com a unidade soberana para a determinação do "caso decisivo": "Pelo fato de que um povo não tenha mais força ou vontade de se manter na esfera do político, não é o político que desaparece do mundo. Desaparece apenas um povo fraco" (SCHMITT, 1992, p. 79).

É evidente que a unidade em questão é o Estado, no qual reside o jus belli que consiste, por sua vez, na "possibilidade real de determinar, em virtude de sua própria decisão, o inimigo, e combatê-lo”. E é presumível que a possibilidade de declarar a guerra a um inimigo incida sobre a vida dos homens compreendidos na unidade do Estado; ela justifica, enquanto tal, o fato de se dirpor da vida dos homens. Nessa medida, a comu- 
nidade política, segundo a estrutura de poder de dominação circunscrita ao Estado, "eleva-se sobre toda outra espécie de comunidade ou sociedade". É sob essa condição ("quando necessário repeli-los fisicamente e lutar com eles") que se afirma um modo de vida ou "forma de existência” diante da sua negação e aniquilamento.

O registro que Schmitt consegue atingir parece, pois, situar-se aquém de qualquer circunscrição categórica estipulada por um cultura tutelada pelo Estado liberal, em que as justificativas sobre a vida dos homens se perdem num entremeado de considerações econômicas, morais, psicológicas etc, todas as quais relativizáveis e apartadas do Estado. Ora, o problema que se encontra nessa consideração de âmbitos é que, uma vez permeados de "princípios individualistas", a disposição para o "sacrifício da vida" é sempre uma contradição, jamais justifica, numa organização econômico-liberal, o fato de que a autoridade política exija dos homens o seu empenho para morte em nome da preservação do seu modo de vida: tratar-se-ia, quando muito, de um "assunto particular" o fato de um indivíduo morrer voluntariamente, quaisquer que fossem os seus motivos pessoais.

No sentido polêmico do político, porém, que, caso viesse à tona, se mostraria despojado dos diversos espectros difusos do projeto liberal, não há normatividade nem ideal que justifique a disposição real para matar outros homens - embora, para Schmitt, tenha sido isso que historicamente subtistuiu a óbvia "vontade de repelir o inimigo" por um "ideal" ou "programa social" de orientação racional. Em suma, tal disposição só faz sentido numa situação de luta efetiva e desidealizada, que tem em conta, na manutenção de seu modo de vida, a existência real do inimigo; do contrário, "exigir dos homens seriamente que eles matem homens e estejam prontos para morrer, a fim de que o comércio e a indústria brilhem para os sobreviventes, ou que progrida o poder de consumo dos netos, é uma atrocidade e uma loucura" (Cf. SCHMITT, 1992, pp.7175). Grosso modo, eis como Schmitt justifica a necessidade do político, então às voltas com a perda de seu sentido específico e, ao mesmo tempo, abrangente.

Ao encontro de tal justificativa, ainda que nuançada por constatações críticas e pelo apelo a um sentido filosófico diverso do texto de Schmitt, situa-se a leitura de Leo Strauss. Nas suas Notas, retoma-se e desdobra-se 


\section{4}

as análises do conceito schmittiano do político, tendo em vista principalmente a abertura crítica aclarada no horizonte liberal.

Cristalizada no contexto da relativização de esferas estanques da ação e do pensamento humanos, a resposta do liberalismo ao político, ou o que ocultou a realidade deste, manifesta-se sob a forma, diz Strauss, de uma "cultura que se afirma enquanto criação soberana (souveräne Schöpfung) [...] do espírito humano". Cabe então questionar a opinião segundo a qual, "não apenas as províncias da cultura (Kulturprovinzen), separadas umas das outras, mas, antes delas, a cultura como um todo é autônoma”. Para Strauss, ignora-se que a noção de cultura sempre pressupõe algo que é cultivado: "cultura é sempre cultura da natureza [...] a cultura dá forma às disposições naturais; é o trato esmerado (sorgfaltig Pflege) da natureza - não importa se da terra ou do espírito humano - e obedece, precisamente por isso, às diretrizes que a natureza mesma dá" (STRAUSS, 1995, p. 97).

Eis o sentido original de cultura para Strauss: tratar a natureza segundo os princípios que ela própria determina. E eis o sentido que ela assume a partir da modernidade: luta (Kampf) contra a natureza. ${ }^{3}$ Além disso, explicita Strauss, “a cultura só pode ser concebida como criação soberana do espírito, caso se pressuponha a natureza como oposição ao espírito, e caso a natureza tenha sido esquecida" (STRAUSS, 1995, p. 98). Ora, a filosofia da cultura, isto é, de uma cultura humana autônoma, é que, ao tomar a natureza como desordem a ser eliminada, "apagou da memória" a autenticidade do "político enquanto status do homem", "enquanto status fundamental e extremo do homem", enfim, "enquanto status naturalis", pondo, no lugar disso, o Estado civil como mantenedor das relações sociais e, simultaneamente, a própria cultura como algo naturalizável, espontaneamente criado. Assim, "se é verdade que a autoconsciência definitiva do liberalismo é a filosofia da cultura, podemos concluir que o liberalismo, envolvido pela segurança de um mundo da cultura, esquece o fundamento da cultura, o estado de natureza, i.e., a natureza humana na sua periculosidade (Gefählichkeit) e no seu estar em perigo (Gefährdetheit)" (STRAUSS, 1995, p.101). ${ }^{4}$

Contudo, mesmo que represente uma abertura crítica no horizonte liberal, a tese schmittiana é problemática aos olhos de Strauss. Ao se posicionar contra o liberalismo, reivindicando, para tanto, uma existência autônoma e concreta do político, corre-se o risco de equivaler a uma 
mera reposição da própria perspectiva liberal da autonomia das províncias da cultura. Com efeito, Strauss reconhece os méritos de Schmitt no enfrentamento da perspectiva liberal. Mas as suas Notas admitem também - de modo bastante discreto, como quem não quer discordar da autoridade de seu interlocutor - que o campo onde Schmitt se move, com vistas ao posicionamento da realidade concreta do político, ainda está atrelado ao predomínio liberal de uma perspectiva segmentada. Isso sem mencionar o problema da autonomia de âmbitos, tratamento esse típico da modernidade. Não fosse o desconforto de ambos os críticos na lógica do liberalismo, a coerência deste seria absoluta.

Desse modo, a despeito de seu esforço, Schmitt não consegue atingir uma base mais fundamental que suplante essa espécie de taxonomia do saber que tipifica os seus proprios âmbitos e despoja-os de qualquer tensão política. Pois o que predomina no cenário liberal é o passo final da modernidade: a perda da dignidade humana, identificada numa mera gratuidade do entertainment (Unterhautung / Spiel). ${ }^{5}$ No jogo antitético dos ramos do saber autorizados pela cultura, que se põe a dar sentido (ou falta de) às orientações da sociedade, é justamente a ausência de lastro que, paradoxalmente, preside essas oposições; nenhuma delas consegue exigir dos homens o sacrificio de suas vidas em nome do político; e, nesse sentido, Strauss revela um elemento ainda mais comprometedor: a adesão de Schmitt à filosofia política de Hobbes indica que o crítico não se dá conta justamente de que neste modelo moderno de soberania se fundamenta o direito natural, passo decisivo da perspectiva do liberalismo, no qual os "indivíduos" passam a agir segundo aquilo que, nos ditames de sua razão, têm como um bem. Em suma, exigir a disposição para a morte, mesmo que Schmitt eleve a soberania hobbesiana ao "Estado total", não parece ser uma exigência coerente: o sacrificio de suas vidas não é mais uma exigência provida do caráter sério (Ernst) do político. Tudo agora pode ser interessante, diz Strauss parafraseando Schmitt, mas não mais do que interessante - ao que Schmitt já havia ponderado em relação ao mundo pacificado:

"um mundo no qual estivesse completamente afastada e desaparecida a possibilidade real de tal confronto, um globo terrestre finalmente pacificado, seria um mundo sem política. Poderia nele existir muitos contrastes, talvez muito interessantes, concorrências e intrigas de toda 
sorte, mas logicamente não haveria qualquer oposição com base na qual se pudesse pedir às pessoas o sacrificio de suas vidas e se permitisse às pessoas o derramamento de sangue e a morte de outras"

(SCHMITT, 1991, p. 61).

Ao fim e ao cabo, Strauss entende que, num mundo "apolítico", Schmitt sente "náusea" em relação a tudo que é interessante (STRAUSS, 1995, p.112). Assim, com a perda da seriedade na disposição para morte, o que Strauss denuncia é o próprio esquecimento de um "interesse" mais digno - sobretudo digno do seu nome - por aquilo que "realmente importa". Quanto ao nome, o fato de Schmitt pressupor a "possibilidade real (wirklich) da morte física" para delimitar o critério do político encobre o que aparece reconditamente na tensão do político, e as Notas de Strauss não hesitam em mostrar o que se encontra por trás dessa "afirmação do político", a saber, "a afirmação da moral".

Se Schmitt já vinha questionando o ideal da liberdade defendido pelo liberalismo, indagando-se "livre para quê?", Strauss, por sua vez, reconsidera a mesma pergunta no contexto do enfrentamento do político na era da despolitização, em que se "luta [apenas] para obter uma base que 'torne possível a segurança, a clareza, o acordo e a paz"” (STRAUSS, 1995, pp. 113-114). Ora, ao que tudo indica o predomínio da perspectiva liberal, além de contaminar a exegese schmittiana do político, no sentido de a luta por si só tornar-se neutra, filia a leitura deste, de maneira bastante sinuosa, às diretrizes modernas da filosofia de Hobbes, segundo Strauss, "o pensador antipolítico", e não, como pretenderia Schmitt, "o único pensador verdadeiramente político” (STRAUSS, 1995, p.102).

Como dissemos, Schmitt afirma o político na possibilidade real de luta. Para tanto, apóia-se na formulação hobbesiana segundo a qual "a natureza da guerra não consiste na luta real, mas na conhecida disposição para tal" [Leviatã XIII]. Assim, enquanto grau de intensidade de associação ou dissociação, o político persevera, mantendo-se em cada momento da história a partir dos mais diferentes motivos, sejam religiosos, nacionais, 
econômicos etc. Mas essa beligerância alternante só é efetivamente realizável graças à guerra, que, segundo Schmitt, "não é, absolutamente, fim e objetivo, sequer conteúdo da política, porém é o pressuposto sempre presente como possibilidade real, a determinar o agir e pensar humanos de modo peculiar, efetuando assim um comportamento especificamente político" (SCHMITT, 1992, p. 60).

A partir da ênfase na possibilidade da guerra, podemos entender como o estado de natureza em Hobbes presta-se ao papel de fundamento do político para Schmitt. Note-se, porém, que em Hobbes a afirmação da autoridade na soberania ocupa uma posição no mínimo ambígua na análise de ambos os críticos - como se um suposto instrumental hobbesiano precisasse sofrer distorções, não deixando escapar o que Hobbes disse, mas extraindo conseqüências com as quais Hobbes não contava: por um lado, busca-se a objetividade autêntica do político na possibilidade da guerra, que é identificado no status belli do estado de natureza, em que "todos são inimigos de todos"; por outro, o projeto civilizador do Estado moderno, de que Hobbes teria sido um dos principais precursores, resulta na negação do estado de natureza, o que representa o abandono do sentido do político.

Por assim dizer, o imperativo hobbesiano está voltado para a paz, graças à soberania do Estado. Aventaríamos, todavia, que no interior da filosofia política de Hobbes o estado de natureza serve como uma hipótese reconstrutora, pelo menos na leitura que aqui propomos: descreve-se a precariedade da vida humana, desprovida da autoridade soberana, sem que se considere se, de fato, tal situação foi ou não experimentada historicamente. Isso nos parece bastante evidente em alguns comentários em nota de Hobbes [De cive, I, 2]: não se especula a existência do estado de natureza ou a sua possível anterioridade em relação ao Estado civil; os homens reconhecem a importância da sociedade "pela educação", não "por natureza"; antes de se tornarem propriamente cidadãos, os homens são como "loucos" ou "crianças", inadequados, portanto, para a sociedade; e, diz Hobbes, "ignoram o beneficio que ela acarreta"; se seguissem apenas o que suas inclinações naturais apontam, tenderiam muito mais ao "domínio do que à associação". Ou seja, Hobbes não tem a pretensão de conferir realidade ao estado de natureza porque o que é dado ao homem, ou o que ele dispõe (no mínimo os seus atributos 
cognitivos e passionais), já se encontra em sociedade, seja na ordem pública perfeita e racionalmente elaborada, seja no contexto de crise institucional. De qualquer modo, a premência do conflito permanece forçosamente no Estado civil porque, de maneira geral, os homens que o constituem jamais sofreram uma transformação radical capaz de alterar a sua natureza passional regrada pelo princípio de autoconservação. No limite, esse estado de natureza na leitura, tanto de Schmitt, quanto de Strauss, vem à baila, no cenário liberal, como uma espécie de projeção às avessas: algo indelével que a civilização tenta encobrir e dissimular, sem se dar conta de um passado esquecido.

Ora, a autenticidade do político schmittiano, que busca o status verdadeiramente humano no "caso sério [ou extremo]" (Ernstfall) da eminência do conflito, seria, segundo essas considerações que indicamos em Hobbes, uma defesa da "miséria humana". Conforme indicado na análise de John P. McCormick, o "medo", mas sobretudo o "medo da morte violenta", é o instrumento elaborado por Hobbes para a gestação do Estado político moderno, pretendendo, pois, controlar a condição conflituosa da humanidade. Isso nos parece fundamental para entender como foi possível a Schmitt e a Strauss separarem um "Hobbes substantivo" de um "Hobbes mecanicista". Valendo-nos das pistas delineadas por McCormick, não se trata mais de um Hobbes que considera a natureza humana má e perigosa, mas aperfeiçoável por ditames racionais (McCORMICK, 1997, pp. 264-265). O Hobbes substantivo guarda em si uma perspectiva proficua em relação à maldade humana, mas, como veremos, insuficiente aos olhos de Strauss. Algo muito mais radical parece estar em jogo aqui, quando se considera a "tarefa urgente" que Strauss assume a partir de um horizonte lançado por Schmitt para além do liberalismo - um intelectual judeu de franca formação no judaísmo ortodoxo, residindo em Paris, solicita, numa carta, em 10 de julho de 1933, a um jurista católico já filiado ao partido nazista e nomeado em maio do mesmo ano para o Conselho de Estado Prussiano, a sua recomendação para participar da preparação da edição das obras completas de Hobbes. (MEIER, 1995, pp. 127-126)

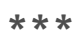

doispontos, Curitiba, São Carlos, vol. 6, n. 3 - especial, p.35-63, abril, 2009 
Em O Conceito do Político, Schmitt diz:

"para os liberais [...] a bondade do homem não significa nada mais do que um argumento com a ajuda do qual o Estado vem a ser colocado ao serviço da "sociedade", exprime, portanto, apenas que a sociedade tem sua ordem em si mesma e que o Estado é apenas seu subalterno, controlado com desconfiança e mantido em limites exatos. [...] $\mathrm{O}$ radicalismo antiestatal cresce na mesma medida da fé na bondade radical da natureza humana".

E um pouco adiante:

"Resta, portanto, a constatação estranha e, para muitos, seguramente inquietante, de que todas as autênticas teorias políticas pressupõem o homem como "mau", isto é, consideram-no como um ser dinâmico e “perigoso” e jamais não-problemático”. (SCHMITT, 1992, pp. 87-88)

Em suma, o ponto de partida "antropológico" da teoria política não pode ser otimista, dada a manutenção da possibilidade real do inimigo, situação que deve ser vista com clareza, já que a "pior das confusões" surge quando conceitos como os de "direito" e de "paz" são empregados de maneira política. No seu fundamento, o político emerge como negação, mais especificamente, como negação de um modo de vida. Do contrário não haveria motivos para agrupamentos sociais. No interior dessa confusão, encontra-se uma valoração do liberalismo que "desqualifica e desmoraliza o inimigo", de acordo com a qual "os homens [...] amam a ilusão de uma tranqüilidade sem perigos e não toleram 'pessimistas", o que por si só é visto por Schmitt como "sintoma" do término do político (SCHMITT, 1991, p. 92). Mas esse sintoma não é senão a própria neutralização que justifica a existência do Estado europeu liberal na passagem do século dezenove para o vinte. Antes disso, no ensejo oitocentista para o progresso intelectual e moral da humanidade, que abandona um período de trevas e se move em direção à ilustração, Schmitt aponta para os sedimentos que permitiram a consolidação do "stato neutrale ed agnostico". Superadas a centralidade histórica das questões metafísicas, morais, políticas, sociais e econômicas, eis que emerge, nessa lógica de deslocamentos de regiões centrais, a era da técnica: "Sob a enorme sugestão de sempre novas e surpreendentes invenções e realiza- 
ções surge uma religião do progresso técnico" em que "a crença nos milagres e no além se transforma logo [...], sem nenhum termo médio, numa religião do milagre da técnica, das realizações humanas e da dominação da natureza. Uma religiosidade mágica passa para uma tecnicidade igualmente mágica" (SCHMITT, 1992, p. 110). A técnica é vista então como uma nova forma de religiosidade ("do entendimento e da reconciliação”) que, por sua vez, se amolda perfeitamente ao ideal pacifista. Do que ela promove não se extrai nenhuma valoração para além da sua própria eficiência, o que assegura por definitivo o esteio da neutralidade, dissipando, ao mesmo tempo, qualquer problemática metafísica, moral, política, entre tantas outras questões outrora centrais:"os problemas puramente técnicos possuem algo de agradavelmente objetivo" (SCHMITT, 1992, p. 115).

Desprovida de valoração, a técnica em contrapartida "serve a qualquer um”, embora não possa ser tomada simplesmente como neutra. Mas o que é ela afinal? "A técnica é sempre e somente instrumento e arma" (SCHMITT, 1992, p. 117). Schmitt mostra-se completamente a par de que, em tempos de neutralidade política, a técnica presta-se como o meio eficiente de dominação das massas, seja, por exemplo, por meio do "monopólio radiofônico", seja até pela "censura cinematográfica". A tendência à neutralização não é, pois, pacifista ao pé da letra. Com efeito, ela só é exercida em virtude da decisão, que pode ser revolucionária ou conservadora, libertária ou opressora, centralizadora ou descentralizadora. Embora não haja questões nem respostas a serem extraídas da técnica, por si só ela concentra e espelha toda a tensão do embate político - o que, na porta de entrada da Segunda Guerra Mundial, permitiria vislumbrar a soleira dos augúrios da Guerra Fria.

Schmitt entende que a técnica tem um espírito - o "espírito da tecnicidade" - que no fundo não tem nada de técnico ou maquinal, pois é fruto de uma "crença" na dominação do homem sobre a natureza. Se "medonho", "fantástico" ou "satânico", isso não é algo que se pode julgar. De qualquer modo, se é possível entrever a tensão do enfrentamento do político no pluriverso das nações, se se tem em conta que a possibilidade do enfrentamento real permanece a determinar o modo de agir de agrupamentos humanos, enfim, se é o político que, mesmo esmaecido, ocultamente vigora, não há como acreditar na neutralidade da 
técnica. A bem dizer, o apelo à paz do ideal liberal não interfere no fato de os Estados - de preferência os mais fortes, os mais doutrinados pelo espírito da tecnicidade e capazes de fazer valer o critério de diferenciação do amigo e do inimigo - saberem empregar os recursos oferecidos pela técnica. E quanto ao sentido último desse uso, Schmitt não demonstra a menor ingenuidade: "sabemos que hoje a guerra mais temível se realiza somente em nome da paz, a mais medonha opressão se realiza em nome da liberdade e a mais terrível desumanidade só em nome da humanidade" (SCHMITT, 1992, p. 119).

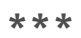

A condição fundamental da possibilidade real da guerra, mesmo como simples disposição, permite a Schmitt radicalizar a sua crítica ao liberalismo: no Estado liberal descentralizado - haja vista o embaraço de suas decisões que se perdem na formalidade de uma democracia representativa comprometida com partidos distintos, cada qual com seus interesses particulares - entrevê-se o estado de natureza no qual todos são potencialmente inimigos de todos. Num sentido mais profundo, a anomia do contexto do liberalismo burguês, que asseguraria o político na sua tensão, não se baseia numa hipótese hobbesiana que reconstruiria antropologicamente as origens da sociedade, tampouco numa retórica que incitaria os homens, uma vez submetidos à autoridade, a combaterem; ela baseia-se, sim, na possibilidade sempre presente de uma necessidade indelével do estado de natureza no interior do Estado. Ao contrário de Hobbes, é no estado de natureza que já se encontram os agrupamentos humanos. E é na sociedade já organizada que se configura e se diferencia o inimigo não sem razão, Schmitt considera que o inimigo é sempre o inimigo público. Portanto, no próprio estado de natureza, melifluamente imiscuído na sociedade organizada, age-se no sentido de preservar a sua ordem, vendo, na alteridade ao seu modo de vida, a premência do perigo.

Podemos dizer então que o inimigo precede o amigo porque, como diz Schmitt, "todo agrupamento humano constitui-se de amigos, já que existe, antes de tudo, o inimigo." Mas, mais do que isso, se o que se busca é o político como fundamento da natureza humana, é preciso defendê- 
lo, i.e., defender a periculosidade humana. A história prova, segundo diversos exemplos escolhidos por Schmitt, e a despeito de uma irrefreável tendência liberal de neutralização de conflitos, que a guerra ainda é uma possibilidade e que a decisão (Entscheidung) de combater o inimigo deriva de um "risco" presente na anomia "tensa" interna à ordem social na anarquia institucionalizada, diríamos - e no modo como os Estados se posicionam entre si na política internacional.

A partir disso, a unidade soberana poderia exigir de seus membros a disposição para a morte, que se sacrificariam em seu nome - tese insustentável em Hobbes, haja vista que, se a morte violenta é o mal maior, o objetivo do Estado é a segurança de seus súditos, e a obediência civil se subordina à proteção. Encontra-se aí, aos olhos arrevesados de Strauss, a passagem subversiva que teria substituído a lei moral do direito clássico (concebida à maneira dos antigos como a obrigação do dever-ser) pelo direito natural moderno (concebido como um direito inalienável e que, no sentido da "ilustração", se exerce livremente). O direito natural é firmado doravante como direito inalienável: defenderse a qualquer preço - expressão cara para Strauss - e escapar da morte até onde for possível são atributos dos quais o homem moderno não está disposto a abrir mão.

Se a crítica que Schmitt dirige ao liberalismo tem o sentido de restabelecer o "lugar de honra" do status naturalis como fundamento da cultura e, nessa mesma esteira, estabelecer o político como "status fundamental e extremo" do homem, num desengano contrário a essa tarefa crítica, Strauss vê, no direito à vida consolidado a partir de Hobbes, a pretensão de uma reivindicação universal, circunscrita ao indivíduo (subjetivo) que, por sinal, precede e determina, em seus esboços (ou arroubos) liberais, o objetivo e os limites do Estado. Ademais, o próprio significado da honra já se mostra prejudicado na modernidade, pois, conforme Strauss indica, no Leviatã [capítulo XXI], a deserção nos campos de batalha corresponde a um ato de "desonra", mas não de "injustiça”, em nada contradizendo o princípio de conservação da vida ou a manutenção da política moderna institucionalizada. Mais adiante, ao citar o segundo livro da trilogia hobbesiana [De Homine, XIII, 9], Strauss decanta uma passagem em que são desmerecidas as virtudes (temeridade, glória e coragem), amplamente bem vistas na tradição política clássica, 
mas que, na modernidade, perdem todo seu caráter enaltecedor, e diz Hobbes: a justiça, i.e., a "não violação das leis civis" é a virtude cardinal do Estado civil, e "negligenciá-las [as leis civis] é um vício". Com exceção da "caridade", virtude por meio da qual seria possível considerar uma moralidade natural, não há nenhuma outra virtude antes da civil life. Todas aquelas que envolvem a imponência de uma virtude guerreira são "úteis", do ponto de vista do indivíduo isolado enquanto tal, mas, na condição de cidadãos, elas são dispensáveis, e diz Hobbes: "não se preserva um Estado por meio da coragem [...] do cidadão" (grifo meu) ${ }^{6}$. O political fact em Hobbes - diferentemente do status político em Schmitt - é apenas o natural right de homens livres e dispostos a reconhecer e a obedecer ao Estado, contanto que este preserve as suas vidas.

Do mesmo modo, o bem do povo (salus populi) em Hobbes se desenreda em quatro pontos: a defesa contra o inimigo externo; a preservação da paz interna; o enriquecimento justo e modesto do indivíduo, obtido mais pela frugalidade e pelo trabalho do que pela guerra; e o desfrute de uma liberdade inofensiva (STRAUSS, 1995, p. 100). Hobbes estaria lutando, nesse caso, contra aquilo que Strauss chama de "natureza não-liberal" do homem, e dando assim os primeiros passos para o posicionamento de uma civilização voltada, conforme assinalara Schmitt, para o "consumo e a produção", em que, na abolição progressiva do político em nome da "humanidade", recrudesce a "inumanidade" (STRAUSS, 1995, p. 105). Com isso, Strauss retoma o ponto tratado por Schmitt segundo o qual o ideal pacifista do mundo moderno - da "segurança a qualquer preço" não se sustenta: em primeiro lugar, porque há uma contradição no fato de haver luta em nome da paz, o que serve, na verdade, para afirmar a possibilidade do combate real; em segundo lugar, de acordo com o critério do político, mesmo a suposta amizade entre os povos, i.e., a unidade política internacional, consistiria, antes, no pluralismo de Estados coexistindo de modo tenso, em que cada soberania busca sustentar o seu modo de ser na ameaça representada pelo outro. Se mesmo a projeção de um Estado mundial se expressa sob forma de um pluriverso, ainda está garantido o conflito que autoriza a decisão de eliminar o risco da alteridade.

Mas se é com vistas ao político que se afirma a periculosidade, com base no que, ou melhor, qual é o elemento da natureza humana, necessário para que se possa contar sempre com um inimigo? 
Sustentar a natureza política do homem como seu caráter fundamental é também considerar, na condição de fato (Faktum), se a sua natureza é boa $(G u t)$ ou má (Böse), o que equivale respectivamente à negação e à posição do político. A respeito disso, Strauss tem em mente que, dada a noção schmittiana de que as "teorias políticas genuínas" pressupõem a periculosidade como posição do político, a "maldade" dos homens em Hobbes é "inocente" e, portanto, não verdadeiramente perigosa. E o que é pior: se tal "confissão de fé antropológica" da maldade for apenas uma suposição, nada impede que a ciência natural vigore cada vez mais, alimentando a crença e a esperança no aperfeiçoamento humano.

A luta que se deflagra no contexto do mal inocente é fruto de meros impulsos de animais embrutecidos, cujos participantes não se deixam levar por nenhum senso moral, mas apenas por alguns atributos (como a cobiça, a inveja, a honra e a glória) relacionados com a vaidade de cada um.

Ora, já na interpretação straussiana da fundação do direito natural, aponta-se o fato de não haver o reconhecimento de nenhum dever-ser originário. Pois, antes de tudo, é o homem que se reconhece como naturalmente livre e estabelece, no desejo de suas reivindicações pessoais, a condição de sua obediência. Sem o "dogma da pecaminosidade", nos diz Strauss, isto é, sem uma lei anterior ao direito natural, esse homem rude de Hobbes, ainda que mau, pode ser educado e adestrado; sua impulsividade mostra-se controlável racionalmente pelo medo da morte violenta, o que, no limite, acaba por suprimir a distinção entre bem e mal. Imerso no panorama liberal, a maldade apregoada por Schmitt precisaria, assim, valer-se dessa acepção de decaída, de covardia, de baixeza e, sobretudo, de "baixeza moral" advinda do pecado original - o que está ausente no seu O Conceito do Político.

De uma maneira tremendamente astuciosa, Strauss entende que, no fundo, a afirmação da periculosidade, como diretriz política que justifica a necessidade de "domínio" (Herrschaft) do Estado sobre a sociedade, precisa ser "reconhecida" - no sentido existencial da inescapabilidade do político - sem ser propriamente "afirmada" (STRAUSS, 1995, p. 111). Mas, ainda assim, a baixeza moral, para não ser mais confundida com um mero impulso animal, não pode ser explicitada moralmente, embora, na origem, "o político [deva] a sua legitimação à seriedade da questão do que é certo" (STRAUSS, 1995, p. 114). Sob as vestes do político, deparamo-nos com a 
ocultada "afirmação da moral". E é justamente o questionamento daquilo que é certo - não só no sentido teológico do "mistério da revelação", mas também à maneira antiga da inconclusa investigação (sképsis) do filósofo grego - que se vê ameaçado pelo acordo a qualquer preço, pela busca de uma base neutra desprovida de querelas.

Ao mesmo tempo, a perda da seriedade vem subsidiada pela tecnologia que transforma a vida numa irrefreável busca de conforto e segurança, sob os auspícios de uma ciência para a qual todos os fins têm o mesmo valor. A ameaça ao status do político, que corresponde à perda da seriedade da vida humana, avizinha-se ao abandono da tarefa outrora assumida pela filosofia política, encobrindo aquilo que Strauss entende como a verdadeira decisão, "a decisão moralmente exigida" que, por sinal, seria a única forma válida de combate contra a cultura do entretenimento - o finis ultimus de um Estado liberal entorpecido. Num cenário de intenso relativismo de valores (e de plena tolerância), onde o máximo que se consegue é ser interessante, ainda não se mostra viável uma passagem capaz de superar o liberalismo, senão dentro de sua própria lógica inescapável.

De outro lado, entende-se que a postura silenciosamente moral de Schmitt tem, para Strauss, o sentido de uma cautela, de uma estratégia argumentativa que, ao partir para a luta, enseja os primeiros passos que permitiriam um desvencilhamento do torpor moral preponderante, no qual todos os valores são relativamente equivalentes.

Nas considerações finais de suas Notas, Strauss mostra os motivos e resultados que estão em jogo no ocultamento do juízo moral em Schmitt. Contra a tolerância pacifista, o que a posição do político permite considerar é uma espécie de afirmação universal da luta, que ignora, segundo Strauss, contra quem se decide lutar. Ora, estamos aqui novamente no terreno da neutralidade criticado por Schmitt, só que com uma "intenção oposta", um liberalismo de sinal invertido, pois se trata agora de uma neutralidade "em relação a todos os agrupamentos de amigos e inimigos" (STRAUSS, 1995, p. 117). Em suma, se o que se busca é ir além da "sistematicidade surpreendentemente consistente do pensamento liberal", cuja cena final é aporética (de uma política antipolítica), então à paz universal assumida pelo Estado moderno contrapõe-se o conflito universal schmittiano, garantindo permanência à possibilidade real da 
guerra, isto é, despojando o homem dos confortos do mundo liberal, para que se retome a ordem das coisas humanas.

Caso viesse à tona, o juízo moral que Schmitt conscientemente esconde sobre o político pareceria arbitrário - característico da sociedade liberal atomizada - e não se posicionaria de modo obrigatório, donde se seguiria a necessidade de o político não ser um fato, mas apenas uma suposição. A moral tacitamente expressa permite a afirmação do político no próprio campo liberal, não como norma ou ideal, sem refutações ou admissões: o político simplesmente é. Trata-se sim do "destino" oriundo da ordem das coisas humanas.

O que se esboça a partir disso é o campo de batalha para a beligerância contra o Estado mecânico, ao que Strauss delimita: "[A] Europa moderna, uma vez posta em marcha - a fim de evitar a disputa sobre a fé justa -, na busca de fundamento neutro enquanto tal, alcançou finalmente a fé na tecnologia". Mostra-se, assim, a razão pela qual, da possibilidade da luta num terreno neutro, o critério do político contrapõe a "fé na tecnologia" à "fé que ainda não tem nome". A fé schmittiana ainda não tem nome porque, diz Strauss, a moral que preside essa fé não encontra espaço para se afirmar numa Europa secularizada. Se não se coloca moralmente em questão contra o que afinal se deve lutar, isso, todavia, favorece ainda mais a polêmica de Schmitt: contra a "moral humanitária", a neutralidade configurada pela técnica oferece a qualquer um a possibilidade de decisão que, para Strauss, vai além de todas as outras decisões. Graças a uma espécie de esclerose múltipla da humanidade com relação a seus fins, os valores complacentes da moral tolerante, acreditando numa bondade humana originária, transformam-se no seu vetor oposto, a saber: para se atingir a "ordem das coisas humanas", cuja compreensão se projeta no sentido mais revelador possível, é necessário renunciar ao status quo de uma sociedade assoberbadamente protegida.

Como se vê, não é propriamente o mundo liberal que se deve combater. $\mathrm{Na}$ verdade, o liberalismo se estabelece como o território neutro que tenta anular o campo de batalha. Contra isso, todas as convicções sérias devem doravante ser respeitadas, de modo a obter a "linha-livre de tiro", sem termos médios, sem negociações, sem que se interfira nos agrupamentos que se comportam segundo o critério do político. A neutralidade que Schmitt consegue atingir não se reduz a uma 
questão privada ou a um juízo particular, "não está fora da realidade do político", e principalmente não evita a decisão. Ela é a abertura de um horizonte, a que nos referimos inicialmente, e não a "última palavra" de Schmitt e, com certeza, nem a de Strauss. ${ }^{7}$

Quanto ao acordo e à paz a qualquer preço, Strauss furta-se ao texto de Schmitt, traçando algumas considerações de próprio punho a partir de uma referência a Platão: "O acordo consiste fundamentalmente e sempre na obtenção, a partir de um meio, de uma meta que está anteriormente bem determinada, embora sempre haja, em relação à mesma meta, a luta (Streit): combatemos com os outros e com nós mesmos sempre e apenas pelo justo (Gerechte) e pelo bom (Gute) [Platão, Eutifronte, 7b-d; Fedro, 263a]" (STRAUSS, 1995, p. 114). O justo e o bom são os fins sobre os quais não há acordo definitivo, embora se possa concordar, "em princípio", quanto aos meios para alcançá-los. Ora, o acordo a qualquer preço representa justamente a tentativa de supressão total de uma disputa, por definição, infindável, que mantém a tensão a partir da qual se cultiva a dignidade humana, mas da qual a modernidade abriu mão. Em outros termos, a paz e o acordo a qualquer preço são a própria renúncia - espécie de artimanha liberal - ao questionamento do sentido da vida, que passa então a privilegiar apenas os meios, vale dizer, o acordo quanto à melhor maneira de fazer as coisas funcionarem, à técnica.

Mas, como indicamos, se não é o liberalismo, quem afinal são os convocados para a batalha? A proposta principal, no incremento contemporâneo do estado de natureza, é despojar-se das benesses conquistadas pelo esforço racional humano apartado do conflito. Para Strauss, Schmitt busca no político a renúncia à segurança e ao conforto do status quo para encontrar o "nada social ou cultural", "o início secreto e básico, a natureza incólume e não corrompida", de modo a emergir, "a partir do poder de um conhecimento puro e completo [...] a ordem das coisas humanas". (STRAUSS, 1995, p. 115). Negar o pecado original é negar a existência do inimigo providencial. Em Hobbes, podemos considerar que, na eliminação da luta de todos contra todos, i.e., no projeto pacifista do Estado civil, a ação humana e a cultura passam a exercer a negação da criação e da providência: o homem está entregue a si mesmo. Conforme Strauss diversas vezes observa, uma vez que a criação da natureza a partir da modernidade é vista de modo 
caótico, pois abandona a humanidade na "indiferença e miséria" do mundo natural, ela não pode ser em Hobbes ponto inicial para se erigir a ordem política. Pelo contrário, superar tal miséria por meio da dominação da natureza é a finalidade do Estado. ${ }^{8}$

Quanto aos reflexos desses textos iniciais, consideremos ainda que em 1938 Schmitt publica O Leviatã na Doutrina de Estado de Thomas Hobbes, tratando do mito do político nas suas diversas manifestações e considerando que, no Deus artificial (ou no grande Leviatã), Hobbes imprimiu o cunho racionalista, a semente de uma fé que afirma a crença na humanidade enquanto tal e que conseqüentemente suprime a ordem teológica:

“[...] a idéia do Estado como um magnum artificium, tecnologicamente

perfeito e criado pelo homem, como uma máquina que tem a sua

'justiça' e a sua 'verdade' apenas em si mesmo - isto é, na sua execução

e funcionamento - foi primeiramente compreendido e

sistematicamente desenvolvido, num conceito claro, por Hobbes"

(SCHMITT, 1996, p. 45).

Tempos depois, em 1959, lecionando, do outro lado do Atlântico, no Departamento de Ciências Políticas na Universidade de Chicago, Strauss publica Sobre as bases da Filosofia Política de Hobbes, em que aprofunda seus estudos sobre o papel de Hobbes no primado da cultura como domínio autônomo, donde mais uma vez se justifica a retomada original da crítica do pensamento hobbesiano, e observa:

“[...] a doutrina de Hobbes não seria estudada seriamente se o

progresso da modernidade fosse separável do declínio da modernidade."

E em seguida:

"A bipartição fundamental entre aquilo que existe independente do fazer humano e aquilo que existe em virtude do fazer humano assemelha-se à bipartição entre natural e artificial, bipartição que Hobbes emprega na distinção entre corpos naturais e corpos artificiais (i.e. Estados). Mas essa semelhança oculta uma diferença mais importante: segundo Hobbes, o artificial compreende não apenas todos os artefatos característicos e a sociedade civil, mas, sobretudo, os 
princípios do entendimento (entendemos apenas aquilo que fazemos). Hobbes tende assim a assumir que o artificial não é apenas irredutível ao natural, mas até mesmo anterior [a este]" (STRAUSS, 1988, p. 182).

A breve interlocução entre os dois intelectuais alemães deu muito que falar. Em última análise, o preço a ser pago pelo projeto moderno de consolidação de um Estado liberal voltado para o bem-estar social é o abandono da distinção bíblica, que, no fim dos tempos, diferencia "os homens redimidos dos não-redimidos".

Mas, num sentido inverso - e arriscaríamos: conservador - o indispensável ao homem não é o seu direito à vida a qualquer preço. O que realmente importa não pode ser respondido pelo próprio homem, mas pela fé na salvação que se equipara pari passu à investigação da classical political philosophy com vistas à melhor ordem política. E a resposta que, na crítica de Schmitt, pode advir ao homem liberal só pode ser respondida por uma questão ainda mais indispensável: obedecer a Deus ou a Satã? Se Satã for o escolhido, então estaremos a caminho de um Estado mundial, que seria a expressão acabada do homem corrompido pela técnica que faz de si um deus, um Leviatã, em cujo cume se encontra a "unidade babilônica". Para Strauss, no entanto, a renúncia ao questionamento do melhor, conclama, em tempos de liberalismo, a uma tarefa mais ambiciosa que a de Schmitt: a busca do conhecimento filosófico do melhor, embora diga respeito a todos, concerne apenas aos que estão cientes de que o melhor não pode ser buscado por todos.

${ }^{1}$ No final de 1932, Strauss deixa Hamburgo para uma breve estada em Paris e, logo depois, em 1933, ruma para Londres, locais em que desenvolve sua pesquisa sobre Hobbes, graças às recomendações de Ernest Cassirer, bem como do próprio Schmitt, para obtenção de uma bolsa de estudos concedida pela Fundação Rockfeller. Em maio de 1933, Schmitt filia-se ao Partido Nacional Socialista e, em julho do mesmo ano, é indicado para o Conselho do Estado Prussiano pelo primeiro ministro Hermann Göring. Há três cartas bastante respeitosas de Strauss endereçadas a Schmitt (13 de março de 1932, 4 de setembro de 1932 e 10 de julho de 1933), não tendo sido encontrada nenhuma resposta de Schmitt a Strauss. Em 9 de outubro de 1933, Strauss escreve para seu amigo Jacob Klein, perguntando-lhe, talvez por ignorância, porque Schmitt não responde às suas cartas; ao que Klein lhe explica de maneira meio cifrada, em 12 de outubro do mesmo ano: "A questão é saber se C. Schm. pode responder! Vejo a 
posição atual dele como absolutamente impossível. Não sei se você tem a imagem. Quanto a isto, também vou the escrever na minha próxima carta, que não lhe enviarei via Alemanha." Em 21 de outubro, Klein escreve novamente para Strauss: "Sobre C.S., pode-se dizer que ele se juntou à multidão de maneira imperdoável. Tendo em conta a posição oficial que ele agora ocupa, não há dúvidas de que ele não pode [lhe] responder [...] E certamente eu não escreveria para ele novamente". Cit. In: MEIER, H. 1995. The Hidden Dialogue, Chicago: The University of Chicago Press, pp. 123-129.

2 Na edição revista de 1963, Schmitt reconsidera: “A autonomia (Selbständigkeit) de nosso critério tem um sentido prático-didático: tornar possível a consideração direta do fenômeno e evitar as muitas categorias e distinções, interpretações e valorações, suposições e prevenções preconcebidas que hoje controlam tal consideração, e que aceitam como válida apenas a sua perspectiva. Quem está em luta com um inimigo absoluto - seja ele o inimigo de classe, de raça ou um inimigo eterno acima do tempo - não está interessado em nossas preocupações relativas ao critério do 'político'; ao contrário, ele vê nisso uma ameaça à sua capacidade imediata de luta, o enfraquecimento através da reflexão, a 'hamletização' e uma relativização suspeita. Por outro lado, as neutralizações que consideram tudo inofensivo transformam o inimigo num simples parceiro (seja de um conflito ou de um jogo) e condenam a nossa pretensão de conhecer uma realidade concreta, acusando-a de belicista, maquiavélica, maniqueísta e - hoje inevitavelmente - nilista. Nas encalhadas alternativas das disciplinas acadêmicas tradicionais, amigo e inimigo aparecem demonizados ou normativizados, ou mesmo traduzidos, axiologicamente, na polaridade valor e não-valor. Nas especializações cada vez mais fragmentadas de uma pesquisa científica funcionalizada, com base na divisão do trabalho, amigo e inimigo surgem mascarados psicologicamente [...] ou mesmo tornam-se uma aparente alternativa de parceiros, calculáveis e manipuláveis. Leitores atentos de nosso ensaio, como Leo Strauss e Helmut Kuhn, observaram de maneira similar que deveríamos nos preocupar apenas em abrir uma estrada, de modo a não nos fecharmos antes de partirmos, e que o problema não era de uma "autonomia das áreas de atividade humana" e nem de "regiões de valor" (SCHMITT, 1992, p.146, com algumas modificações minhas).

3 Pode-se considerar que a concepção straussiana de natureza, como um momento "pré-científico", perpassa toda a sua obra. Strauss entende a natureza como pressuposto da organização da vida humana, pressuposto esse esquecido e substituído pelo de uma cultura que se arroga o título de autônoma. Para Robert Pippin, o conceito de natureza em Strauss encontra a sua matriz em Rousseau. Cf. PIPPIN, R. 1995. The Modern World of Leo Strauss. In: KIELMANSEGG, P. G. et alli (Orgs.) Hannah Arendt and Leo Strauss, German Emigrés and American Political Thought after World War II. Cambridge: Cambridge University Press.

${ }^{4}$ De certa forma, a crise na República de Weimar - que para Strauss não pode ser justificada apenas por motivos econômicos, uma vez que diversas democracias liberais suportaram o colapso de 1929 [Cf. Strauss, L. 1984. Spinoza's Critique of Religion. Chicago:The University of Chicago Press, p. 3] - espelha a idéia de que o "esquecimento da natureza" procede de um hiato talvez insuperável entre a antiguidade clássica e o mundo moderno. Em linhas gerais, Strauss vê esse mundo antigo à luz da pólis grega, que se caracterizava não necessariamente pelo viés democrata ateniense, mas pela própria tarefa filosófica de questionamento da best political order. Ora, tal questionamento se mostra vetado pelo panorama liberal, que se afirma como o melhor, ou pelo menos não parece comportar espaço para pôr-se, ele próprio, em questão,

doispontos, Curitiba, São Carlos, vol. 6, n. 3 - especial, p.35-63, abril, 2009 
mesmo numa situação de debilidade política. O cultivo original, considerado por Strauss, obedece à natureza, aprende com ela, de maneira modelar, tomando-a como ordem a ser seguida. Com a modernidade, a concepção de natureza passa a ser de uma realidade desordenada, miserável, precária e, portanto, perigosa, deixando os homens à mercê de conquistas individuais para sua proteção. Em suma, a natureza é que originalmente antecede e autoriza a cultura. Todavia, dado o esquecimento, e imerso num progressivo aperfeiçoamento (Verbesserung) tecnicizado do mundo, a noção da autonomia de uma cultura despolitizada é que toma força.

5 Segundo Altini, na edição de 1963 de O Conceito do Político, Schmitt leva em conta o grifo de Strauss sobre o termo Unterhaltung, presente na primeira edição de 1927, e o substitui posteriormente por Spiel ("que deve ser traduzido por play"), querendo com isso acentuar uma maior oposição ao "sério" (Ernst). Cf. ALTINI, C. 2004. La teoria della filosofia come filosofia política. Pisa: Edizione ETS.

6 Sobre a mudança de suas bases morais, Hobbes admitia inicialmente (quando da sua tradução da Guerra do Peloponeso, de Tucídides) a audácia, coragem, e bravura como virtudes aristocráticas vinculadas à honra, fundamentais, portanto, na execução da guerra. Depois disso, renega-as ao estado de natureza, passando exclusivamente a privilegiar, a partir da idéia de prudência, o "medo da morte violenta", enquanto paixão que planeja e executa e, portanto, enquanto "base de todas as virtudes". Quatro anos depois de suas Notas, Strauss publica em 1936 A filosofia política de Thomas Hobbes, em que salienta o papel da "temeridade", que podemos tomar aqui como sinônimo de "periculosidade", misto de coragem e glória, mas que só pode ser tomada por virtude no estado de natureza: "A bravura (valour) pode ser a virtude de uma profissão particular, de um soldado - [mas] ela deixa de sê-lo enquanto virtude humana" In: STRAUSS, L. 1951. The Political Philosophy of Thomas Hobbes. Chicago: The University of Chicago Press, p. 114.

7 Pode parecer que esta nota, em função de seu apelo à nossa contemporaneidade (mais especificamente nos idos de 1980), seja um despropósito, haja vista o clamor fervoroso do contexto quando do debate entre Schmitt e Strauss. Contudo, trata-se de um comentário de Allan Bloom (aluno de Strauss) a propósito da massificação do rock and roll junto ao surgimento do aparelho de fone de ouvido (Walkman headphones). Para Bloom, os jovens estudantes americanos parecem animais nus, sem as vestes da civilização segundo os ideais dos "pais fundadores" da democracia americana, enfim, sem nada pelo que viver ou morrer, e Bloom comenta de modo sarcástico: "A revolução sexual deve derrotar (overthrow) todas as forças de dominação, os inimigos da natureza e da felicidade. Do amor surge o ódio, mascarando-se como reforma social. Uma visão de mundo equilibra-se sobre um ponto de apoio sexual. Aquilo que uma vez foi ressentimento imaturo, inconsciente ou semiconsciente, torna-se uma nova Sagrada Escritura. E então aparece o desejo por uma sociedade sem classes, livre de preconceitos, sem conflitos, uma sociedade universal que resulta necessariamente de uma consciência liberada - "We are the World", uma versão pubescente de Alle Menschen werden Brüder, cuja realização foi inibida pelas equivalências políticas entre Mãe e Pai. Estes são os três grandes temas líricos: sexo, ódio e uma versão pegajosa e hipócrita de amor fraterno. [...] Uma olhadela nos vídeos que projetam imagens no muro da caverna de Platão, desde que a MTV assumiu o seu controle, prova isso. Nada de nobre, sublime, profundo, delicado, de bom gosto, ou mesmo decente, pode encontrar lugar num tal tableaux." BLOOM,A. 1987. The Closing of the American Mind. New York: Simon \& Schuster Paperbacks, p. 74.

doispontos, Curitiba, São Carlos, vol. 6, n. 3 - especial, p.35-63, abril, 2009 
8 Em relação a essa "miséria”, Strauss afeta alguma surpresa diante do fato de Hobbes ter acreditado que pudesse erigir uma ordem política where there was so much cause of dispair [i.e. no estado de natureza]. Cf. STRAUSS, L. 1992. Natural Right and History, Chicago: The University of Chicago Press, p. 175. Ora, o que está em causa aqui é a ausência na sociedade de uma virtude moral. No mesmo sentido, passando, porém, da teleologia de Atenas para a teologia de Jerusalém, a "Divina Providência" reduz-se em Hobbes a uma questão de fé - de que "Jesus é o Cristo". E a honra a Deus (reconhecer o seu poder e bondade) é apenas para obtenção de seus favores. Segundo Strauss, se não há conhecimento de Deus, isso para Hobbes é motivo suficiente para que não se considere Deus como autor da lei moral. Mesmo um soberano pagão deve ser obedecido enquanto tal. A única virtude que se tem em mãos, e que serve como álibi para fundar o Estado, é o direito natural de autoconservação de cada indivíduo. Em alusão, talvez, às referências bíblicas de Schmitt, a secularização na modernidade política, nesse seu enigmático progresso do esquecimento, substituiu a queda adâmica pelo estado de natureza, e o estado de graça pela sociedade civil, fazendo desta a salvação da humanidade, ainda que completamente desprovida de um finis ultimus ou de um summum bonum, o que o próprio Hobbes confirma no início do capítulo XI do Leviatã. (Cf. Strauss, L. idem, p. 184. Cf. ainda Drury, S. B. 2005. The Political Ideas of Leo Strauss, Palgrave Macmillan, p. 135, em que a autora menciona que bastaria ao Estado, na nação kantina, os demônios ilustrados e egoístas).

\section{Referências bibliográficas}

ALTINI, C. 2004. La teoria della filosofia come filosofia política. Pisa:

Edizione ETS.

BLOOM, A. 1987. The Closing of the American Mind. New York: Simon $\&$ Schuster Paperbacks.

DRURY, S. B. 2005. The Political Ideas of Leo Strauss. New York: Palgrave Macmillan.

HOBBES, T. 2003. Leviatã. São Paulo: Martins Fontes.

MCCORMICK, J. P. 1997. Carl Schmitt's Critique of Liberalism: against politics as technology. Cambridge: Cambridge University Press.

PIPPIN, R. 1995. The Modern World of Leo Strauss. In:

KIELMANSEGG, P. G. et alli (Orgs.) Hannah Arendt and Leo Strauss,

German Emigrés and American Political Thought after World War II.

Cambridge: Cambridge University Press. 
SCHMITT, C. 1992. O Conceito do Político. Petrópolis:Vozes. (Der Begriff der Politischen. In: Archiv für Sozialwissenschaft und Socialpolitik, LVIII, 1927, nº. 1, pp. 1-33) .

SCHMITT, C. 1996. The Leviathan in the State Theory of Thomas Hobbes: Meaning and Failure of a Political Symbol. Greenwood Press.

STRAUSS, L. 1995. Strauss's Notes on Schmitt's Concept of the Political. In: MEIER, H. The Hidden Dialogue. Chicago: The University of Chicago Press. (Anmerkungen zu Carl Schmitt "Der Begriff des Politischen", In: Archiv für Sozialwissenschaft und Socialpolitik (Tübingen), vol. $67, n^{\circ} .6$ (agosto - setembro, 1932) pp. 732-749.

STRAUSS, L. 1984. Spinoza's Critique of Religion. Chicago: The University of Chicago Press.

STRAUSS, L. 1988. On the Basis of Hobbe's Political Philosophy. In: STRAUSS, What is Political Philosophy?. Chicago: The University of Chicago Press.

STRAUSS, L. 1951. The Political Philosophy of Thomas Hobbes. Chicago: The University of Chicago Press. 